GRASAS Y ACEITES 70 (1)

January-March 2019, e287

ISSN-L: 0017-3495

https://doi.org/10.3989/gya.0233181

\title{
The effect of temperature on rice oil bleaching to reduce oxidation and loss in bioactive compounds
}

\author{
M.M. Strieder ${ }^{a}$, J.I. Engelmann ${ }^{a}$, R.S. Pohndorf ${ }^{b}$, P.A. Rodrigues ${ }^{a}$, R.S. Juliano ${ }^{a}$, G.L. Dotto ${ }^{c}$ \\ and L.A.A. Pinto ${ }^{a, \square}$ \\ ${ }^{\text {a }}$ School of Chemistry and Food, Federal University of Rio Grande, FURG, Italia Avenue, km 08, 96203-900, \\ Rio Grande, RS, Brazil. \\ ${ }^{b}$ Department of Agroindustrial Science and Technology, Federal University of Pelotas, Pelotas, RS, Brazil. \\ ${ }^{c}$ Chemical Engineering Department, Federal University of Santa Maria, UFSM, 1000 Roraima Avenue, \\ 97105-900, Santa Maria, RS, Brazil \\ ${ }^{\square}$ Corresponding author: dqmpinto@furg.br
}

Submitted: 26 February 2018; Accepted: 02 July 2018

SUMMARY: Refining conditions are very important to obtain high-quality rice oil. This work aimed at evaluating the effect of bleaching temperature in chemical and physical refining processes to avoid losses in $\gamma$-oryzanol and carotenoids. In addition, the aspects related to rancidity were investigated. Samples of degummed oil (obtained by a physical procedure) and of neutralized oil (obtained by a chemical procedure) were provided by a local industry. The oils were bleached at 80,95 and $110^{\circ} \mathrm{C}$ using $1 \%\left(\mathrm{w} \mathrm{w}^{-1}\right)$ activated earth. The temperature of $95^{\circ} \mathrm{C}$ was the best in relation to oxidative stability. The $\gamma$-oryzanol and carotenoids were better preserved through physical refining than by the chemical procedure by about 64 and $84 \%$, respectively. However, the oxidation indicators were high for the oil bleached by the physical procedure, indicating that bleaching without prior neutralization is viable, but it is necessary to obtain an industrial crude oil with less oxidation.

KEYWORDS: Carotenoids; Chlorophylls; Peroxides; Refinement; $\gamma$-oryzanol

RESUMEN: Efecto de la temperatura de decoloración del aceite de arroz para reducir la oxidación y pérdida de compuestos bioactivos. Las condiciones de refinación son muy importantes para obtener un aceite de arroz de alta calidad. Este trabajo tuvo como objetivo evaluar el efecto de la temperatura de decoloración en la refinación química y física, para evitar pérdidas de $\gamma$-oryzanol y carotenoides. Además, se investigaron aspectos relacionados con el enranciamiento. Las muestras de aceite desgomado (obtenido por procedimiento físico) y aceite neutralizado (obtenido por procedimiento químico) fueron suministrados por una industria local. Los aceites se decoloraron a 80,95 y $110{ }^{\circ} \mathrm{C}$ usando $1 \%\left(\mathrm{w} \cdot \mathrm{w}^{-1}\right)$ de tierra activada. La temperatura de $95^{\circ} \mathrm{C}$ fue la mejor en relación con la estabilidad oxidativa. El $\gamma$-oryzanol y los carotenoides se conservaron mejor tras la refinación física que mediante la química, en aproximadamente un $64 \%$ y un $84 \%$, respectivamente. Sin embargo, los indicadores de oxidación fueron más altos para el aceite decolorado por procedimiento físico, lo que indica que la decoloración sin neutralización previa es viable, pero es necesario obtener un aceite crudo industrial con menos oxidación.

PALABRAS CLAVE: Carotenoides; Clorofilas; Peróxidos; Refinación; $\gamma$-oryzanol

ORCID ID: Strieder MM https://orcid.org/0000-0002-0925-0220, Engelmann JI https://orcid.org/0000-0001-72448195, Pohndorf RS https://orcid.org/0000-0002-3498-8542, Rodrigues PA https://orcid.org/0000-0001-8148-0891, Juliano RS https://orcid.org/0000-0001-9348-4195, Dotto GL https://orcid.org/0000-0002-4413-8138, Pinto LAA https://orcid.org/0000-0002-4477-0686

Citation/Cómo citar este artículo: Strieder MM, Engelmann JI, Pohndorf RS, Rodrigues PA, Juliano RS, Dotto GL, Pinto LAA. 2019. The effect of temperature on rice oil bleaching to reduce oxidation and loss in bioactive compounds. Grasas Aceites 70 (1), e287. https://doi.org/10.3989/gya.0233181

Copyright: (C2019 CSIC. This is an open-access article distributed under the terms of the Creative Commons Attribution 4.0 International (CC BY 4.0) License. 


\section{INTRODUCTION}

Vegetable oils are a good source of lipids and antioxidant compounds for a healthy human diet, and rice oil is unique because it contains a great deal of $\gamma$-oryzanol (Pestana-Bauer et al., 2012). $\gamma$-oryzanol is a mixture of ferulic acid esters of sterol and triterpene alcohols, and has been studied because of its antioxidant, anti-inflammatory, anticancer and anti-diabetic properties (Juliano et al., 2005; Jha and Panchal, 2017). Maintaining the carotenoids found in rice oil during the refining steps is important as they have antioxidant effects and prevent oil rancidity (Vaskova and Buckova, 2015; Silva et al., 2014). In addition, $\beta$-carotene is an essential vitamin which is required for proper body functioning and a deficiency in this vitamin is linked to many chronic diseases.

Crude oils contain non-glyceride compounds which must be removed to obtain oil with a desirable light color, mild taste and oxidative stability (González-Tovar et al., 2005). The refining process can be carried out either physically or chemically (Torres-González et al., 2009). A degumming step using phosphoric acid (chemical refinement) or hot water (physical refinement) to remove phospholipids and gums (Kreps et al., 2014) is typically applied. In a neutralization step, the free fatty acids are removed through the addition of an alkali solution of sodium hydroxide. A bleaching step aims to remove pigments, oxidation products and traces of metals, using adsorbent substances (Marrakchi et al., 2015). Some vegetable oils have a high wax content, which is separated from the oil in the winterization step (de-waxing) by cooling the oil and allowing the waxes to crystallize or through the use of solvents (Baümler et al., 2007). In physical refining an alkaline solution is not used to neutralize the oil. I It also prevents nutrient losses that occur in chemical refining (Pestana-Bauer et al., 2012). The degumming-neutralization (chemical refining) steps lead to the greatest reduction in bioactive components (Zhu et al., 2016). According to Paucar-Menacho et al., (2007), at least $90 \%$ of the $\gamma$-oryzanol present in crude rice oil is lost during the neutralization step.

Bleaching is the third step in the classical refining process of vegetable oil. This is an adsorption operation aimed at the elimination of substances which provide color to vegetable oil, such as chlorophyll and carotenoids. This process also results in the removal of oxidation products, thus promoting its stability against oxidation (Strieder et al., 2017; García-Moreno et al., 2013). The temperature, the type and amount of adsorbent, the contact time and vacuum are variables of the bleaching process and temperature is an important factor because heat promotes interactions between the adsorbent and the adsorbate (Pohndorf et al., 2016b). The composition and antioxidant activity of the oil can change the thermal condition used during refining and heat can promote oxidative reactions in oil (Olmedo et al., 2015; Güneşer et al., 2017). In the oil industry, the temperature of rice oil bleaching is approximately $110^{\circ} \mathrm{C}$, but the process consumes large amounts of energy which represent high costs (Pestana-Bauer et al., 2012; Köseoglu and Engelgau, 1990).

The aim of this work was to evaluate the refining type (chemical or physical) and the effect of temperature on oil bleaching in carotenoid reduction and $\gamma$-oryzanol loss. In addition, the aspects related to hydrolytic and oxidative rancidity were investigated.

\section{MATERIALS AND METHODS}

\subsection{Materials}

Degummed and neutralized rice oil, and activated earth (Tonsil Supreme $110 \mathrm{FF}$ with the following characteristics: average particle diameter of $68 \pm$ $7 \mathrm{~mm}$, specific surface area of $245 \pm 12 \mathrm{~m}^{2} \cdot \mathrm{g}^{-1}$, pore diameter of $2.00 \pm 0.05 \mathrm{~nm}$, bulk density (460 \pm 10 $\mathrm{kg} \cdot \mathrm{m}^{-3}$ ) and real density of $2150 \pm 10 \mathrm{~kg} \cdot \mathrm{m}^{-3}$ ) were provided from a rice oil processing industry located in the city of Pelotas, Brazil. The oil samples were stored at $-20{ }^{\circ} \mathrm{C}$ in amber containers to avoid oxidation until use.

\subsection{Bleaching assays}

The parameters used in the bleaching process, such as time, temperature and amount of adsorbent, depend on the oil type and adsorbent characteristics. The optimum temperature range for the bleaching of traditional vegetable oil reported by Shahidi (2005) was from 85 to $110{ }^{\circ} \mathrm{C}$. The bleaching assays were performed using $30 \mathrm{~g}$ of degummed (physical refining) or neutralized oil (chemical refining). The oil samples were heated at temperatures of 80 , 95 or $110^{\circ} \mathrm{C}$, under constant stirring $(40 \mathrm{rpm})$ and vacuum. Afterward, $1 \%(\mathrm{w} / \mathrm{w})$ of activated earth was added in each assay, and the bleaching was performed for $20 \mathrm{~min}$ (Pohndorf et al., 2016a). The adsorbent was separated from the rice oil at $60{ }^{\circ} \mathrm{C}$ by filtration in a vacuum, with a pre-coat of diatomaceous earth, for $15 \mathrm{~min}$. The experimental assays were performed in triplicate.

\subsection{Oils quality analyses}

The oxidative quality of the oil was determined in terms of free fatty acids (FFA), peroxide value (PV) and anisidine value (AnV) according to the methods: Ca 5a-40, Cd 8-53 and Cd 18-90 (AOCS, 2017), respectively. The oil color was determined according to the method $\mathrm{Cc}$ 13e-92 (AOAC, 2017) using a Lovibond Tintometer (Lovibond Color STALER Tintometer, model F, UK), with a $5^{1} \%_{4}$ " cell, by varying the yellow (Y) and red (R) colors and fixing the 
blue (B) color at unit zero. All analyses were carried out in triplicate. The total oxidation value (TOTOX value) was determined according to Equation 1:

$$
\text { TOTOX }=(2 \times \mathrm{PV})+\mathrm{An} \mathrm{V}
$$

where PV is the peroxide value (meq $\mathrm{kg}^{-1}$ ) and $A n V$ is the anisidine value.

The chlorophyll content was obtained through the absorbance, performed in triplicate, according to Sabah (2007), in Equation 2:

$$
\mathrm{Cl}=\left[\frac{\mathrm{A}_{670}-\left(\mathrm{A}_{630}-\mathrm{A}_{710}\right) / 2}{0.0964 \mathrm{LM}}\right] \mathrm{V}
$$

where $\mathrm{Cl}$ is the chlorophyll content $\left(\mathrm{mg}_{\text {pheophytin-a }}\right.$ $\left.\mathrm{kg}^{-1}{ }_{\text {oil }}\right), \mathrm{A}_{710}, \mathrm{~A}_{670}$ and $\mathrm{A}_{630}$ are the absorbance wavelengths, respectively, of 670,630 and $710(\mathrm{~nm}), \mathrm{V}$ is the volume of hexane $(\mathrm{mL}), \mathrm{L}$ the length of the cuvette $(\mathrm{cm})$ and, $\mathrm{M}$ is the mass of the oil sample $(\mathrm{g})$.

\subsection{Quantification of bioactive compounds}

The $\gamma$-oryzanol content was determined according to Bucci et al., (2003). The oil samples were diluted in isopropyl alcohol and read in a spectrophotometer at wavelengths of $327 \mathrm{~nm}$, in triplicate, according to Equations 3 and 4:

$$
\begin{gathered}
\mathrm{C}_{\mathrm{GO}}=\frac{\mathrm{A}_{327}}{\mathrm{~L}} \\
\mathrm{TGO}_{\mathrm{E}-\mathrm{UV}}=\left(\frac{\mathrm{C}_{\mathrm{GO}}}{\mathrm{C}_{\mathrm{DIL}}}\right) \times 100
\end{gathered}
$$

where $\mathrm{C}_{\mathrm{GO}}$ is the $\gamma$-oryzanol content in the oil solution $\left(\mathrm{g}_{\text {oryzanol }} \mathrm{L}^{-1}\right), \mathrm{A}_{327}$ is the absorbance at 327 $\mathrm{nm}, \mathcal{E}$ is the specific extinction coefficient ( $\mathrm{L} \mathrm{g}_{\text {oryzanol }}$ $\mathrm{cm}^{-1}$ ), which is $33.82 \mathrm{~L} \cdot \mathrm{g}^{-1} \cdot \mathrm{cm}^{-1}$ (in isopropyl alcohol solvent), $\mathrm{TGO}_{\mathrm{E}-\mathrm{UV}}$ is the $\gamma$-oryzanol content $(\% \mathrm{~m}$ $\mathrm{m}^{-1}$ ) and $\mathrm{C}_{\mathrm{DIL}}$ is the oil concentration in the diluted solution $\left(\mathrm{g} \cdot \mathrm{L}^{-1}\right)$.

The carotenoid content in the rice oil was determined by the spectrometric method, taking readings of the oil diluted in hexane $\left(10 \% \mathrm{~m} \cdot \mathrm{v}^{-1}\right)$ at $446 \mathrm{~nm}$, in tripicate, according to Equation 5 (Mustapa et al., 2011):

$$
\mathrm{C}=\frac{383 \times \mathrm{A}_{446}}{\mathrm{Lc}}
$$

where $\mathrm{C}$ is the carotenoid content $\left(\mathrm{mg} \mathrm{kg}^{-1}\right), \mathrm{A}_{446}$ is the absorbance at $446 \mathrm{~nm}, \mathrm{~L}$ is the length of the cuvette $(\mathrm{cm}), \mathrm{c}$ is the oil concentration in hexane $\left(\mathrm{g} \cdot 100 \mathrm{~mL}^{-1}\right)$ and 383 is the extinction coefficient for carotenoids.

\subsection{Identification of functional groups}

The identification of functional groups of the degummed, neutralized and bleached oils at the best temperature was analyzed by Fourier transform infrared spectroscopy with attenuated total reflectance (FT-IR-ATR) (Prestige 21, 210045, Japan). The spectra were recorded in the $4.000-600 \mathrm{~cm}^{-1}$ region, with a resolution of $4 \mathrm{~cm}^{-1}$.

\subsection{Thermal analyses}

The melting curves of the neutralized, degummed and bleached oils (at the best temperature) were analyzed by differential scanning calorimetry (DSC). The melting point was obtained by DSC (Shimadzu, DSC-60, Japan) equipped with a liquid nitrogen cooling system. Samples $(5 \mathrm{mg})$ were hermetically sealed in aluminum pans and cooled to $-50^{\circ} \mathrm{C}$ and then heated to $60^{\circ} \mathrm{C}$ at a rate of $10^{\circ} \mathrm{C} \cdot \mathrm{min}^{-1}$.

The thermogravimetric curves were obtained in a thermobalance with a nitrogen flow of $50 \mathrm{~mL} \cdot \mathrm{min}^{-1}$ and a heating rate of $10^{\circ} \mathrm{C} \cdot \mathrm{min}^{-1}$. The samples were placed in aluminum pans and heated in the temperature range of 20 to $500{ }^{\circ} \mathrm{C}$ (Garcia et al., 2004). All thermal analyses were carried out in triplicate.

\subsection{Statistical analysis}

Comparisons among the bleached, neutralized and degummed oil samples were made by analysis of variance and Tukey's test at $95 \%$ confidence $(\mathrm{p}<0.05)$, using the Statistic 7.0 software. The assays were made in triplicate.

\section{RESULTS AND DISCUSSIONS}

\subsection{Characterization of the raw materials}

Some aspects related to the quality of degummed and neutralized oil prior to the bleaching step are shown in Table 1. The free fatty acids, peroxide and anisidine values, chlorophyll content and $\gamma$-oryzanol content were lower in the neutralized oil, with the exception of the carotenoid content. This occurred because of the addition of the sodium hydroxide solution in the neutralization step, which reacted with the free fatty acids forming the soaps, which carried peroxides, aldehyde and $\gamma$-oryzanol. The loss in $\gamma$-oryzanol was $87 \%$ in the neutralization step. A high amount of free fatty acids in the degummed oil was verified, which indicates that the rice bran was not effectively inactivated, allowing the action of the lipases in the triacylglycerols (Paucar-Menacho et al., 2007). The crude oil showed a Lovibond color of $57.5 \mathrm{Y} / 12.1 \mathrm{R}\left(5^{1} / 4\right.$ " cell $)$, and for the degummed oil and the neutralized oil the colors were of $70.0 \mathrm{Y} / 3.8$ and $77.0 \mathrm{Y} / 2.5 \mathrm{R}$, respectively. 


\subsection{Quality aspects of the bleached oil}

The effects of temperature and refining method on some quality characteristics of rice oil are shown in Table 2. The initial concentration of free fatty acids (FFA) in the oil is important in the refining process due to its influence in the neutralization and bleaching steps, and the different levels are due to variations in sources of crude oil (Lin and Lin, 2005). The bleached oil from degummed oil (BDO) showed a reduction of about $30 \%$ in FFA (Table 2), indicating the adsorption of this compound. However, the bleached oil from the neutralized oil (BNO) showed a small increase in FFA. A similar result was obtained for soybean oil by Lin and Lin (2005), who verified that the initial adsorption rate of FFA was increased by the increase in the initial FFA concentration. Silva et al., (2014) also verified a small increase in the FFA values in the bleaching step of neutralized palm oil. This can be explained

TABLE 1. Characterization of degummed and neutralized industrial rice oils by acidity, peroxide, anisidine, and Totox values and their contents in carotenoids, chlorophylls and $\gamma$-oryzanol.

\begin{tabular}{lcc}
\hline Property & Degummed oil & Neutralized oil \\
\hline $\begin{array}{l}\text { Free fatty acids, FFA } \\
\left(\mathrm{mgKOH} \cdot \mathrm{g}^{-1}\right)\end{array}$ & $10.79 \pm 0.14$ & $\mathrm{ND}$ \\
$\begin{array}{l}\text { Peroxides value, } \\
\left.\text { PV (meq } \mathrm{O}_{2} \cdot \mathrm{kg}^{-1}\right)\end{array}$ & $7.19 \pm 0.24^{\mathrm{a}}$ & $4.53 \pm 0.50^{\mathrm{b}}$ \\
$\begin{array}{l}\text { Anisidine value, AnV } \\
\text { TOTOX value }\end{array}$ & $59.9 \pm 2.8^{\mathrm{a}}$ & $7.8 \pm 0.5^{\mathrm{b}}$ \\
$\begin{array}{l}\text { Chlorophyll content } \\
\left(\mathrm{mg} \cdot \mathrm{kg}^{-1}\right)\end{array}$ & $74.3 \pm 2.3^{\mathrm{a}}$ & $16.9 \pm 1.5^{\mathrm{b}}$ \\
$\begin{array}{l}\text { Carotenoids content } \\
\left(\mathrm{mg} \cdot \mathrm{kg}^{-1}\right)\end{array}$ & $11.18 \pm \pm 2.52^{\mathrm{a}}$ & $15.39 \pm 1.34^{\mathrm{b}}$ \\
$\gamma$-oryzanol $(\%)$ & $10.89 \pm 0.24^{\mathrm{a}}$ \\
\hline
\end{tabular}

Mean values \pm standard deviations (in triplicate, $n=3$ ). Values followed by different letters in the same line show difference according to bTukey's test at $95 \%$ significance $(\mathrm{p}<0.05)$. ND: not detected. by the heating, which favored oil oxidation during bleaching.

Despite the reduction in FFA in the BDO, the content was high and may have favored oxidation reactions which generated peroxides, mainly in the temperature of $80{ }^{\circ} \mathrm{C}$ (Table 2). Oil oxidation is favored by several factors, such as the composition of fatty acids, type of oxygen, and compounds such as pigments, metals, antioxidants, and free fatty acids (Choe and Min, 2006). Therefore, the presence of free fatty acids along with the heat provided by the operation could have favored the formation of peroxides at $80{ }^{\circ} \mathrm{C}$. At other temperatures, there was no increase or decrease in this value. This can be due to the acid-activated earth, which catalytically decomposes peroxides in secondary oxidation products (Silva et al., 2014) and, thus, at other temperatures, decomposition may have occurred. For the BNO it was observed that a reduction of about $75 \%$ occurred in the peroxide value for any temperature analyzed. The same behavior was verified by Strieder et al., (2017), who found the value of 2.7 meq $\cdot \mathrm{kg}^{-1}$ for rice oil bleached at $110{ }^{\circ} \mathrm{C}$. According to Moigradean et al., (2012), the amount of peroxide in vegetable oil indicates its oxidative level and, thus, its tendency to become rancid.

In the oxidation reaction, the primary oxidation products are decomposed into minor substances such as aldehydes, which lead to a rancid smell and taste in the oil. These compounds are determined by the anisidine value (Moigradean et al., 2012; Marina et al., 2009). In Tables 1 and 2, an increase in the anisidine value can be seen for the BNO, indicating the formation of secondary oxidation products during the bleaching step. The temperature could have favored secondary oxidation because the peroxide content decreased and formed aldehydes in this step (Silva et al., 1999). The high anisidine values in the BDO can be associated with the high content presented in the degummed oil. It can be seen that the anisidine value was not increased by the bleaching step, and was even reduced at temperatures of

TABLE 2. Characterization of the bleached rice oils after the degumming and neutralization steps by the values of acidity, peroxide, anisidine, and Totox values and their contents in carotenoids, chlorophylls and $\gamma$-oryzanol.

\begin{tabular}{lcccccc}
\hline Property & BDO 80 $^{\circ} \mathbf{C}$ & BDO 95 $^{\circ} \mathbf{C}$ & BDO 110 $^{\circ} \mathbf{C}$ & BNO 80 $^{\circ} \mathbf{C}$ & BNO 95 $^{\circ} \mathbf{C}$ & BNO 110 $^{\circ} \mathbf{C}$ \\
\hline Free fatty acids, FFA $(\%$ linoleic acid & $7.57 \pm 0.33^{\mathrm{a}}$ & $7.51 \pm 0.01^{\mathrm{a}}$ & $7.79 \pm 0.03^{\mathrm{a}}$ & $0.17 \pm 0.01^{\mathrm{b}}$ & $0.17 \pm 0.01^{\mathrm{b}}$ & $0.17 \pm 0.01^{\mathrm{b}}$ \\
Peroxides value, PV $\left(\mathrm{meq} \mathrm{O}_{2} \cdot \mathrm{kg}^{-1}\right)$ & $15.67 \pm 1.53^{\mathrm{a}}$ & $8.15 \pm 1.36^{\mathrm{b}}$ & $8.40 \pm 0.25^{\mathrm{b}}$ & $2.94 \pm 0.83^{\mathrm{c}}$ & $0.99 \pm 0.27^{\mathrm{d}}$ & $1.08 \pm 0.43^{\mathrm{d}}$ \\
$p$-Anisidine value, AnV & $51.9 \pm 1.1^{\mathrm{b}}$ & $49.6 \pm 3.1^{\mathrm{b}}$ & $62.1 \pm 0.5^{\mathrm{a}}$ & $10.1 \pm 2.2^{\mathrm{c}}$ & $9.4 \pm 1.6^{\mathrm{c}}$ & $10.4 \pm 0.8^{\mathrm{c}}$ \\
TOTOX value & $83.2 \pm 4.1^{\mathrm{a}}$ & $65.9 \pm 0.4^{\mathrm{b}}$ & $78.9 \pm 3.9^{\mathrm{a}}$ & $16.0 \pm 3.9^{\mathrm{c}}$ & $11.4 \pm 2.2^{\mathrm{d}}$ & $12.5 \pm 1.6^{\mathrm{d}}$ \\
Chlorophyll $\left(\mathrm{mg} \cdot \mathrm{kg}^{-1}\right)$ & $25.15 \pm 1.09^{\mathrm{a}}$ & $16.69 \pm 2.19^{\mathrm{b}}$ & $22,50 \pm 1.20^{\mathrm{a}}$ & $5.89 \pm 0.20^{\mathrm{c}}$ & $3.77 \pm 0.12^{\mathrm{d}}$ & $2.30 \pm 0.41^{\mathrm{d}}$ \\
Carotenoids $\left(\mathrm{mg} \cdot \mathrm{kg}^{-1}\right)$ & $13.54 \pm 0.24^{\mathrm{a}}$ & $10.68 \pm 1.24^{\mathrm{b}}$ & $13.12 \pm 0.90^{\mathrm{b}}$ & $5.28 \pm 0.38^{\mathrm{c}}$ & $3.88 \pm 0.09^{\mathrm{d}}$ & $4.11 \pm 0.53^{\mathrm{d}}$ \\
$\gamma$-oryzanol $(\%)$ & $1.09 \pm 0.04^{\mathrm{a}}$ & $1.12 \pm 0,03^{\mathrm{a}}$ & $0.92 \pm 0,08^{\mathrm{b}}$ & $0,17 \pm 0,01^{\mathrm{c}}$ & $0,17 \pm 0,01^{\mathrm{c}}$ & $0.16 \pm 0,01^{\mathrm{c}}$ \\
\hline
\end{tabular}

Mean values \pm standard deviation (in triplicate, $\mathrm{n}=3$ ). Values followed by different letters in the same line show differences by Tukey's test at 95\% significance $(\mathrm{p}<0.05)$. BDO: bleached degummed oil; BNO: bleached neutralized oil. 
80 and $95^{\circ} \mathrm{C}$, indicating that aldehyde was absorbed at these temperatures.

The TOTOX value indicates total oxidation in the oil, which includes primary and secondary compounds formed in the oxidative reactions (Moigradean et al., 2012). It can be observed in Table 2 that the lowest values for the $\mathrm{BDO}$ and $\mathrm{BNO}$ were obtained at the temperature of $95^{\circ} \mathrm{C}$, indicating that this temperature favored adsorption and promoted less oxidation than the other temperatures. The leaching of rice oil is an endothermic process (Pohndorf et al., 2016a), and at temperatures of $80^{\circ} \mathrm{C}$ and 110 ${ }^{\circ} \mathrm{C}$ the adsorption capacities were lower and, consequently, the TOTOX values were higher.

Some pigments, such as chlorophylls, favor oxidation reactions in oil, and therefore, it is important to remove it (Choe and Min, 2006). The chlorophyll content was reduced by about $26 \%$ in all bleaching assays of neutralized oil (Tables 1 and 2), but in the BDO there was a small increase. This may be justified by the exposure time and heat applied in the bleaching step, which, according to Sabah (2007), promotes pheopigment formation from chlorophylls. The temperature of $80^{\circ} \mathrm{C}$ was less efficient to remove chlorophyll, due the fact that the heat supply was not sufficient for the operation. According to Ponhdorf et al., (2016a), who studied the bleaching step at 100,110 and $120^{\circ} \mathrm{C}$, chlorophyll molecules require more energy to be removed from rice oil. The Lovibond colors for BDO and BNO presented values of around $50.0 \mathrm{Y} / 10.5 \mathrm{R}$ and $11.4 \mathrm{Y} / 2 \mathrm{R}$, respectively.

Chemical refining was more efficient for removing oxidation compounds, especially because the degummed oil presented a great amount of these compounds. In addition, the temperature of $95^{\circ} \mathrm{C}$ was the best for promoting a good interaction between adsorbent and adsorbate, which is not so high a temperature to cause oxidation.

\subsection{Bioactive compounds in the bleached oil}

The presence of carotenoids in the oil is interesting because they are natural antioxidants which assist in the maintenance of quality and increase nutritional value (Vaskova and Buckova, 2014). Tables 1 and 2 show that the carotenoid values were reduced in BNO but remained constant in BDO. Similar results for the carotenoid content in bleached rice oil were found by Strieder et al., (2017), using 1\% of an activated earth/activated carbon blend at $110^{\circ} \mathrm{C}$, obtaining an oil with $5.7 \mathrm{mg} \cdot \mathrm{kg}^{-1}$. According to their study, activated carbon is better than activated earth for maintaining carotenoid levels in rice oil.

In Table 2, the bleaching step presented a loss of approximately $40 \%$ in the $\gamma$-oryzanol content in the BDO, but this loss was well below what occurred when the oil was degummed and neutralized $(90 \%)$. At $110^{\circ} \mathrm{C}$ there was a greater reduction in $\gamma$-oryzanol for the bleached oil obtained from degummed oil. $\gamma$-oryzanol was indicated by Spiazzi et al., (2013) as being one of the main antioxidant components in rice oil, thus, it is very important for preserving the quality of the oil; however, the refined commercial oil presents only about $0.16 \mathrm{~g}$ of $\gamma$-oryzanol per $\mathrm{kg}$ of oil due to losses during chemical refining (Paucar-Menacho et al., 2007). Thus, it can be said that the better process for maintaining carotenoids and $\gamma$-oryzanol was physical refining at temperatures of 80 and $95{ }^{\circ} \mathrm{C}$, because at $110^{\circ} \mathrm{C}$ more loss occurred.

\subsection{Identification of functional groups by FTIR spectra}

The spectra of the degummed, neutralized and bleached oils at the best temperature studied $\left(95^{\circ} \mathrm{C}\right)$ is shown in Figure 1. The spectra for the oils were very similar, with the exception of the band of $3200-3600 \mathrm{~cm}^{-1}$, which is visible in the oils before the bleaching step. This can be attributed to the vibration stretching of $\mathrm{OH}$, which indicates the presence of polar compounds in the oil, such as peroxides, hydroperoxides and traces of moisture. After bleaching, the peak was less evident because this operation removed these compounds. In addition, the functional groups of the rice oil were observed, with the band at $3005 \mathrm{~cm}^{-1}$ corresponding to stretching $\mathrm{CH}$ of the cis double bands of unsaturated fatty acids. The bands at 2917 and $2854 \mathrm{~cm}^{-1}$ refer to the asymmetric and symmetric vibration stretching of the $\mathrm{CH}_{2}$ functional group, respectively. The band at $1744 \mathrm{~cm}^{-1}$ is related to the carbonyl ester group $\mathrm{C}=\mathrm{O}$ of triglycerides. The band at $1653 \mathrm{~cm}^{-1}$ is associated with the stretching

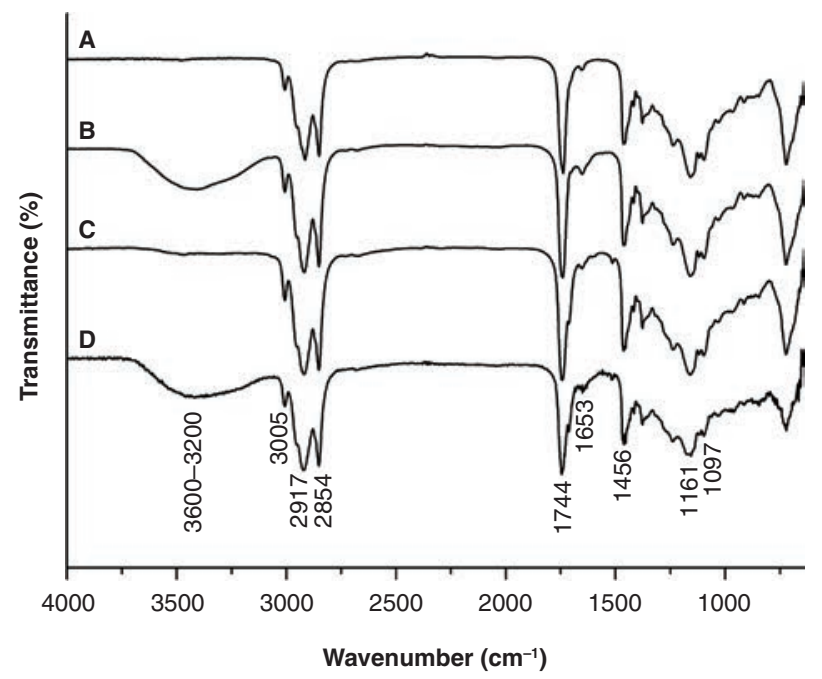

FIGURE 1. FT-IR spectra of lipids of degummed rice oil (A), of neutralized rice oil $(\mathrm{C})$ and of bleached rice oil obtained at $95^{\circ} \mathrm{C}$, with degummed oil (B) and neutralized oil (D). Mean values in triplicate $(\mathrm{n}=3)$. 
vibration of the double bands between carbons $\mathrm{C}=\mathrm{C}$. The band at $1456 \mathrm{~cm}^{-1}$ refers to the bending (scissoring) of the $\mathrm{CH}_{2}$. The bands at 1161 and $1097 \mathrm{~cm}^{-1}$ are related to the stretching vibration of the ester groups $\mathrm{C}-\mathrm{O}$ (Ponhdorf et al., 2016b).

\subsection{Thermal properties of rice oil}

Figure 2 shows the melting temperatures of the degummed oil, BDO, neutralized oil and BNO at $-7.22,-19.44,-15.99$ and $-18.94{ }^{\circ} \mathrm{C}$, respectively. A reduction in the melting temperature in the bleached oils was observed. The melting temperature indicates the oil composition in triacylglycerols, and therefore, it is possible that the pigments, free fatty acids and oxidation compounds increased the melting temperature of the oil. The melting temperatures of $\mathrm{BDO}$ and $\mathrm{BNO}$ were similar, and they were close to the values found by Strieder et al., (2017), who found $-17.53^{\circ} \mathrm{C}$ for bleached rice oil.

The thermogravimetric curves of the oils are shown in Figure 3I. It was verified that the decomposition of triacylglycerols occurred in the temperature range from $220{ }^{\circ} \mathrm{C}$ to $450{ }^{\circ} \mathrm{C}$. The degummed oil and BDO (curves A and B) started the degradation at a lower temperature than the neutralized oil and BNO (curves C and D). This can be due to the oxidation compounds present in degummed oil. These compounds absorb part of the energy incited on the sample, causing a decrease in the degradation temperature (Huang and Sathivel, 2010). Besides that, the first stage of oil's decomposition is the most important value for the characterization of thermal stability according to Szabo et al., (2012).
Thus, it can be inferred that the oil was more stable after the bleaching step and that the BNO was the most stable.

In Figure 3II, the curves show that the temperature of maximum mass loss rate was $400{ }^{\circ} \mathrm{C}$ for all oils. It can also be observed that the curves of degummed oil and DBO presented a second degradation point between 200 and $250{ }^{\circ} \mathrm{C}$, associated with the presence of oxidation compounds.

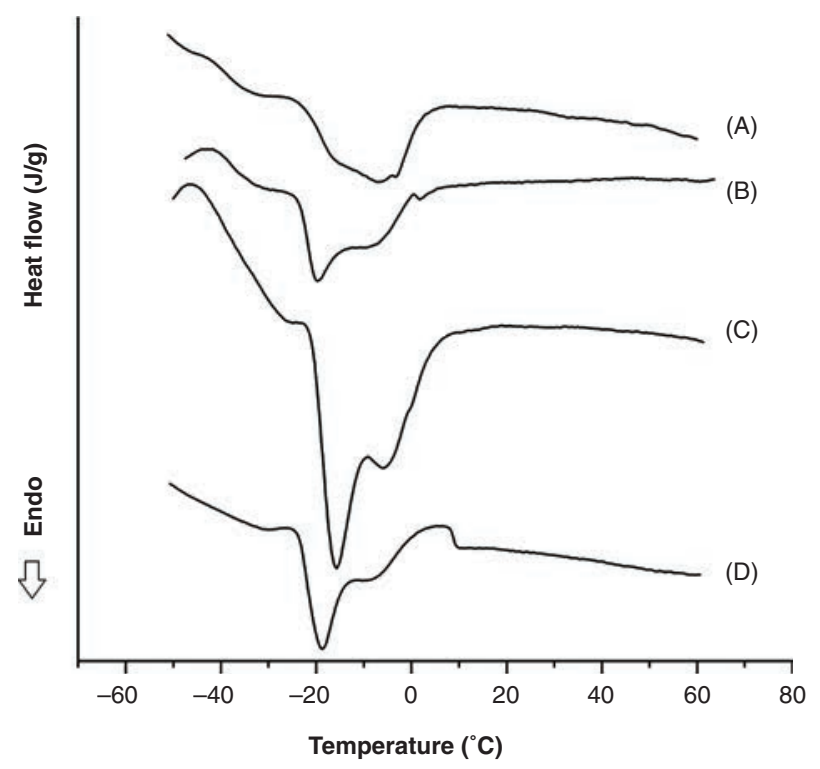

FIGURE 2. Melting curves (DSC) of degummed rice oil (A), neutralized rice oil (C) and bleached rice oil obtained at $95^{\circ} \mathrm{C}$, with degummed oil (B) and neutralized oil (D). Mean values in triplicate $(\mathrm{n}=3)$.

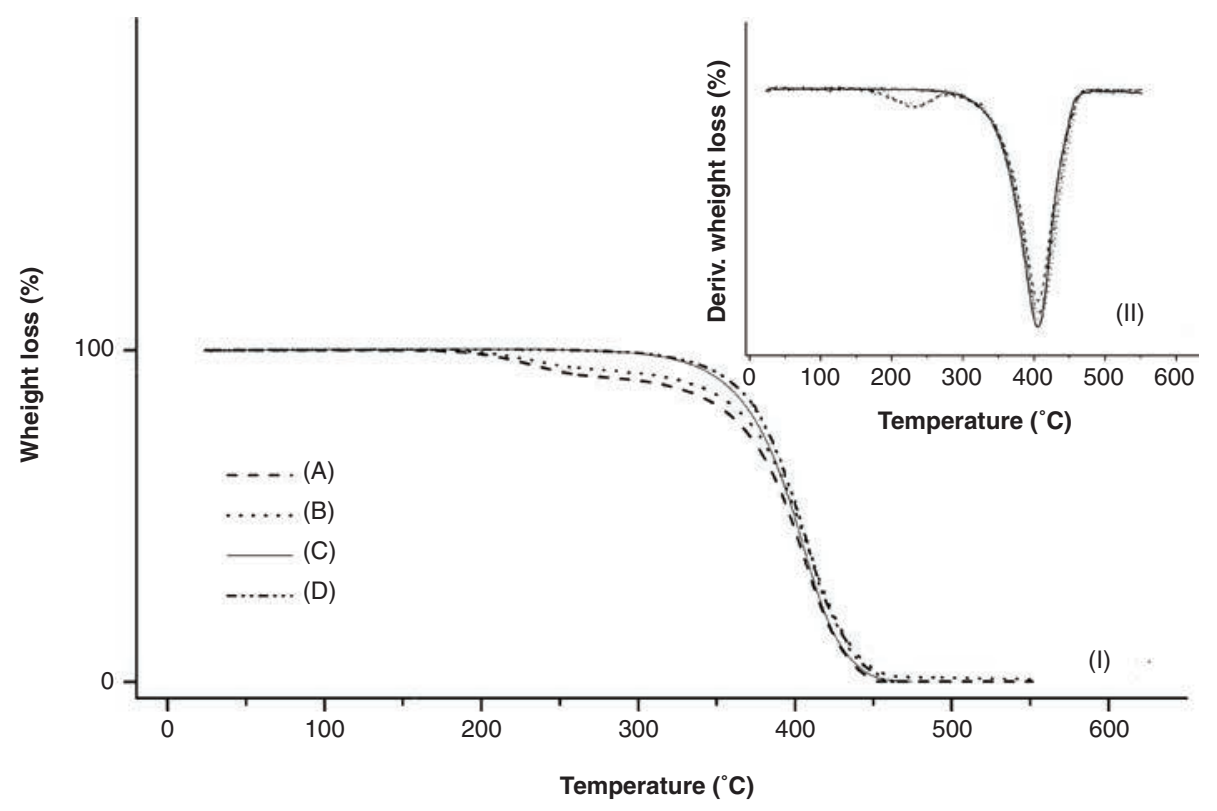

FIgURE 3. TGA curves (Graphic I) and DrTGA curves (Graphic II) of degummed rice oil (A), neutralized rice oil (C) and bleached rice oil obtained at $95^{\circ} \mathrm{C}$, with degummed oil (B) and with neutralized oil (D). Mean values in triplicate (n = 3). 


\section{CONCLUSIONS}

In this work it was determined that the best temperature for the bleaching step of neutralized and degummed industrial rice oil was $95{ }^{\circ} \mathrm{C}$. In addition, it was possible to verify that for the reduction in oxidation compounds (free fatty acids, peroxides and aldehydes) it was necessary to perform a neutralization step, even though a degumming step was performed physically. It was possible to determine through DSC curves that the pigments, free fatty acids and oxidation compounds increased the melting temperature of the oil. Based on TGA curves, it can be verified that the oils were more stable after the bleaching step and that the bleached oil obtained with neutralized oil (BNO) was the most stable. The FTIR spectra of the degummed, neutralized and bleached oils at the best temperature studied $\left(95^{\circ} \mathrm{C}\right)$ were very similar. However, after the bleaching step the vibration stretching peak of $\mathrm{OH}$ was less intense because this peak indicates the presence of polar compounds in the oil, such as peroxides, hydroperoxides and traces of moisture. It was observed that the bleached rice oil obtained with degummed oil provides an oil which is more rich in $\gamma$-oryzanol, indicating that the bleaching step without a previous neutralization step is viable for maintaining this compound, but it is necessary to use an industrial crude oil with a lower grade of oxidation.

\section{ACKNOWLEDGMENTS}

The authors are grateful to the CAPES/Brazil (Coordination for the Improvement of Higher Education Personnel) and $\mathrm{CNPq} /$ Brazil (National Council for Scientific and Technological Development) for their financial support.

\section{REFERENCES}

AOCS. 2017. Official methods and recommended practices of the American Oil Chemist's Society, 7th ed. Urbana, IL: AOCS Press.

Baümler ER, Crapiste GH, Carelli AA. 2007. Sunflower-oil wax reduction by seed solvent washing. J. Am. Oil Chem. Soc. 84, 603-608. https://doi.org/10.1007/s11746-007-1074-0

Bucci R, Magri AD, Magri AL, Marini F. 2003. Comparison of three spectrophotometric methods for the determination of $\gamma$-oryzanol in rice bran oil. Anal. Bioanal. Chem. 375, 1254-1259. https://doi.org/10.1007/s00216-002-1700-5

Choe E, Min DB. 2006. Mechanisms and factors for edible oil oxidation. Comp. Rev. in Food Sci. and Safety 5, 169-186. https://doi.org/10.1111/j.1541-4337.2006.00009.x

Jha AB, Panchal SS. 2017. Neuroprotection and cognitive enhancement by treatment with $\gamma$-oryzanol in sporadic Alzheimer's disease. J. Appl. Biomed. In Press. https://doi. org/10.1016/j.jab.2017.05.001

García-Moreno PJ, Guadix A, Gómez-Robledo L, Melgosa M, Guadix EM. 2013. Optimization of bleaching conditions for sardine oil. J. Food Eng. 116, 606-612. https://doi. org/10.1016/j.jfoodeng.2012.12.040

Garcia JU, Santos HI, Fialho AP, Garro FLT, Antoniosi Filho NR, Leles MIG. 2004. Estudo da estabilidade térmica de óleos de peixes em atmosfera de nitrogênio. Ecl. Quím. 29, 41-46. https://doi.org/10.1590/S0100-46702004000200006

González-Tovar LA, Noriega-Rodríguez JA, Ortega-García J, Gámez-Meza N, Medina-Juárez LA. 2005. Cinética de adsorción de pigmentos, peróxidos y tocoferoles durante el proceso de blanqueo del aceite de soja. Grasas Aceites 56, 324-327. https://doi.org/10.3989/gya.2005.v56.i4.100

Güneşer BA, Yilmaz E, Ok S. 2017. Cold pressed versus refined winterized corn oils: quality, composition and aroma. Grasas Aceites 68, 1-12. https://doi.org/10.3989/ gya. 1168162

Huang J, Sathivel, S. 2010. Purifying salmon oil using adsorption, neutralization, and a combined neutralization and adsorption process. J. Food Eng. 96, 51-58. https://doi. org/10.1016/j.jfoodeng.2009.06.042

Juliano C, Cossu M, Alamanni MC, Piu L. 2005. Antioxidant activity of gamma-oryzanol: Mechanism of action and its effect on oxidative stability of pharmaceutical oils. Int. J. Pharm. 299, 146-154. https://doi.org/10.1016/j. ijpharm.2005.05.018

Kreps F, Vrbiková L, Schmidt Š. 2014. Influence of industrial physical refining on tocopherol, chlorophyll and beta-carotene content in sunflower and rapeseed oil. Eur. J. Lipid Sci. Technol. 116, 1572-1582. https://doi.org/10.1002/ ejlt.201300460

Köseoglu SS, Engelgau DE. 1990. Membrane applications and research in the edible oil industry: An assessment. $\mathrm{J}$. Am. Oil Chem. Soc. 67, 239-269. https://doi.org/10.1007/ BF02540650

Lin H-R, Lin C-I. 2005. Kinetics of adsorption of free fatty acids from water-degummed and alkali-refined soy oil using regenerated clay. Sep. Purif. Technol. 44, 258-265. https://doi.org/10.1016/j.seppur.2005.01.014

Marina AM, Man YBC, Nazimah SAH, Amin I. 2009. Chemical properties of virgin coconut oil. J. Am. Oil Chem. Soc. 86, 301-307. https://doi.org/10.1007/s11746-009-1351-1

Marrakchi F, Kriaa K, Hadrich B, Kechaou N. 2015. Experimental investigation of processing parameters and effects of degumming, neutralization and bleaching on lampante virgin olive oil's quality. Food Bioprod. Process. 94, 124-135. https://doi.org/10.1016/j. fbp.2015.02.002

Moigradean D, Poiana M-A, Gogoasa I. 2012. Quality characteristics and oxidative stability of coconut oil during storage. J. Agroaliment. Proc. Technol. 18, 272-276.

Mustapa AN, Manan ZA, Azizi CYM, Setianto WB, Mohd Omar AK. 2011. Extraction of $\beta$-carotenes from palm oil mesocarp using sub-critical R134a. Food Chem. 125, 262267. https://doi.org/10.1016/j.foodchem.2010.08.042

Olmedo RH, Asensio CM, Grosso NR. 2015. Thermal stability and antioxidant activity of essential oils from aromatic plants farmed in Argentina. Ind. Crops Prod. 69, 21-28. https://doi.org/10.1016/j.indcrop.2015.02.005

Paucar-Menacho LM, Silva LH, Sant'ana AS, Gonçalves LAG. 2007. Refino de óleo de farelo de arroz (Oryza sativa L.) em condições brandas para preservação do $\gamma$-oryzanol. Cienc. Tecnol. Aliment. 27, 45-53. https://doi.org/10.1590/ S0101-20612007000500009

Pestana-Bauer VR, Zambiazi RC, Mendonça CRB, BeneitoCambra M, Ramis-Ramos G. 2012. $\gamma$-Oryzanol and tocopherol contents in residues of rice bran oil refining. Food Chem. 134, 1479-1483. https://doi.org/10.1016/j. foodchem.2012.03.059

Pohndorf RS, Cadaval Jr TRS, Pinto LAA 2016a. Kinetics and thermodynamics adsorption of carotenoids and chlorophylls in rice bran oil bleaching. J. Food Eng. 185, 9-16. https://doi.org/10.1016/j.jfoodeng.2016.03.028

Pohndorf RS, Pinheiro CP, Pinto LAA. 2016b. Kinetic study of adsorption of pigments and oxidation products in the bleaching of rice bran oil. Int. J. Food Eng. 12, 211-219. https://doi.org/10.1515/ijfe-2015-0164

Sabah E. 2007. Decolorization of vegetable oils: Chlorophyll-a adsorption by acid-activated sepiolite. J. Colloid. Interface Sci. 310, 1-7. https://doi.org/10.1016/j.jcis.2007.01.044

Santos FW. 2013. $\gamma$-Oryzanol protects against acute cadmium-induced oxidative damage in mice testes. Food 
Chem. Toxicol. 55, 526-532. https://doi.org/10.1016/j. fct.2013.01.048

Shahidi F. 2005. Edible oil and fat products: edible oils. In: Bailey's Industrial Oil and Fat Products, 6th ed., v. 2. New York: Wiley \& Sons. ISBN: 978-0-471-38460-1

Silva FAM, Borges MFM, Ferreira MA. 1999. Métodos para avaliação do grau de oxidação lipídica e da capacidade antioxidante. Quim. Nova 22, 94-103. https://doi.org/10.1590/ S0100-40421999000100016

Silva SM, Sampaio KA, Ceriani R, Verhé R, Stevens C, De Greyt W, Meirelles AJA. 2014. Effect of type of bleaching earth on the final color of refined palm oil. LWT Food Sci. Technol. 59, 1258-1264. https://doi.org/10.1016/j.lwt.2014.05.028

Spiazzi CC, Manfredini V, Da Silva FEB, Flores EMM, Izaguirry AP, Vargas LM, Soares MB, Santos FW. 2013. $\gamma$-Oryzanol protects against acute cadmium-induced oxidative damage in mice testes. Food Chem. Toxicol. 55, 526-532. https:// doi.org/10.1016/j.fet.2013.01.048

Strieder MM, Pinheiro CP, Borba VS, Pohndorf RS, Cadaval Jr TRS, Pinto LAA. 2017. Bleaching optimization and winterization step evaluation in the refinement of rice bran oil. Sep. Purif. Technol. 175, 72-78. https://doi. org/10.1016/j.seppur.2016.11.026

Szabo M-R, Chambre D, Iditoiu C. 2012. TG/DTG/DTA for the oxidation behavior characterization of vegetable and animal fats. J. Therm. Anal. Calorim. 110, 281-285. https:// doi.org/10.1007/s10973-012-2253-2

Torres-González M, Angulo-Guerrero O, Oliart-Ros RM, Medina-Juárez LA. 2009. Efecto de la refinación física sobre la calidad química y sensorial del aceite de coco. Grasas Aceites 60, 96-101. https://doi.org/10.3989/gya.043608

Vaskova H, Buckova M. 2015. Thermal degradation of vegetable oils: spectroscopic measurement and analysis. Procedia Eng. 100, 630-635. https://doi.org/10.1016/j. proeng.2015.01.414

Zhu M, Wen X, Zhao J, Liu F, Ni Y, Ma L, Li J. 2016. Effect of industrial chemical refining on the physicochemical properties and the bioactive minor components of Peanut oil. J. Am. Oil Chem. Soc. 93, 285-294. https://doi.org/10.1007/ s11746-015-2776-3 